\section{Idaho Water Use, 2015}

The ability to quantify water resources hinges on the understanding of water use by the population. The demand humans place on the water cycle varies across the United States, driven by both need and availability. The U.S. Geological Survey quantifies water use nationally, at the county scale, with estimates of water withdrawals and deliveries, by category of use (for example, irrigation, thermoelectric power, industrial, public supply, including domestic deliveries and self-supply domestic, livestock, mining, and aquaculture) and source (fresh and saline groundwater or surface water) every 5 years (Dieter and others, 2018).

Estimates of water use are an important component of the water budget to help manage water supplies and plan for the future. Understanding water use in Idaho is important not only at the local (county) and State scales, but also at the National level because Idaho ranked third in the Nation for total water use in 2015 (C.A. Dieter, U.S. Geological Survey, written commun., 2018).

This fact sheet describes calendar year 2015 freshwater withdrawals by source and by each Idaho county. An associated data release (Murray, 2018) provides the data discussed herein.
Freshwater withdrawals totaled 17,737 million gallons per day (Mgal/d) during 2015. Surface water accounted for 70 percent of total withdrawals for all categories of use, mostly for irrigation of crops and aquaculture production (fig. 1). Withdrawals for mining activities were mostly from surface water, whereas the remaining categories of use - public supply, domestic, industrial, livestock, irrigation of golf courses, and thermoelectric power-relied largely on groundwater withdrawals (fig. 1). Most withdrawals occurred in southern Idaho counties to support irrigated agriculture (fig. 2).

\section{Top Three Water Uses}

Irrigation, aquaculture, and public supply/domestic water withdrawals totaled $17,534 \mathrm{Mgal} / \mathrm{d}$ in 2015, accounting for more than 99 percent of total withdrawals for all categories (fig. 3). Other categories of use - industrial, livestock, mining, irrigation of golf courses, and thermoelectric power-accounted for less than 1 percent of Idaho's total withdrawals in 2015.

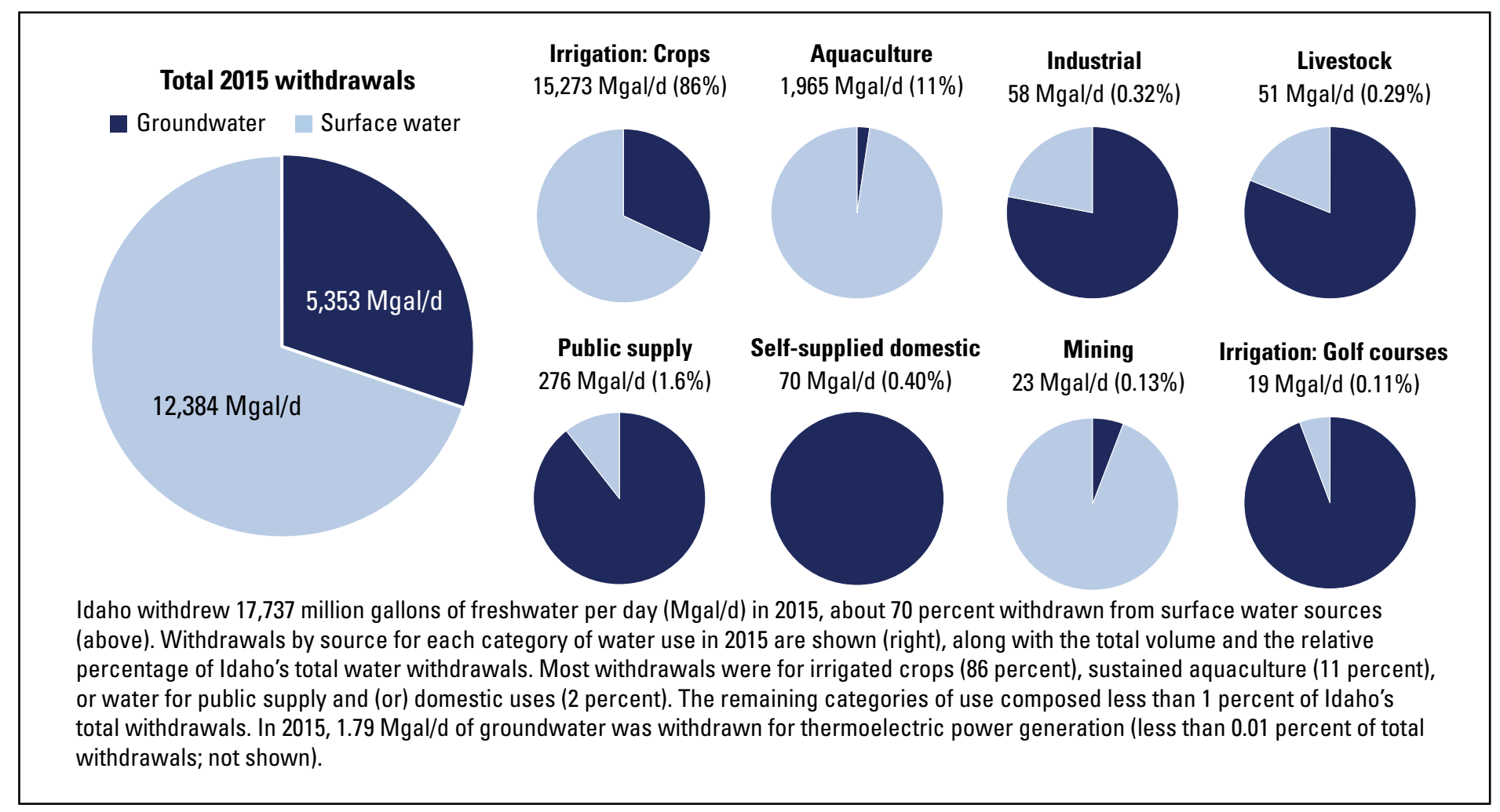

Figure 1. Withdrawals by source and category in Idaho, 2015. 


\section{Irrigation-15,273 million gallons per day}

Estimated withdrawals to irrigate nearly 3.78 million acres of crops in Idaho was $15,273 \mathrm{Mgal} / \mathrm{d}(17,108,000$ acre-feet per year) in 2015, accounting for 86 percent of total water withdrawn for all uses (fig. 1). Although most of Idaho's crops were irrigated from surface water sources (primarily the Snake River), irrigation was also the largest use of Idaho groundwater withdrawals (4,882 Mgal/d; 91 percent of 2015 Idaho groundwater withdrawals). In 2015, crops consumptively used an estimated 58 percent of these total withdrawals - the remaining 42 percent was returned to the water cycle by conveyance losses, surface runoff, and infiltration. In 2015, irrigation withdrawals were the second largest in the United States, behind only California (C.A. Dieter, U.S. Geological Survey, written commun., 2018). The Western United States relies heavily on applied irrigation water, especially where seasonal rainfall is not sufficient to support healthy crops. Estimated withdrawals include all water diverted for

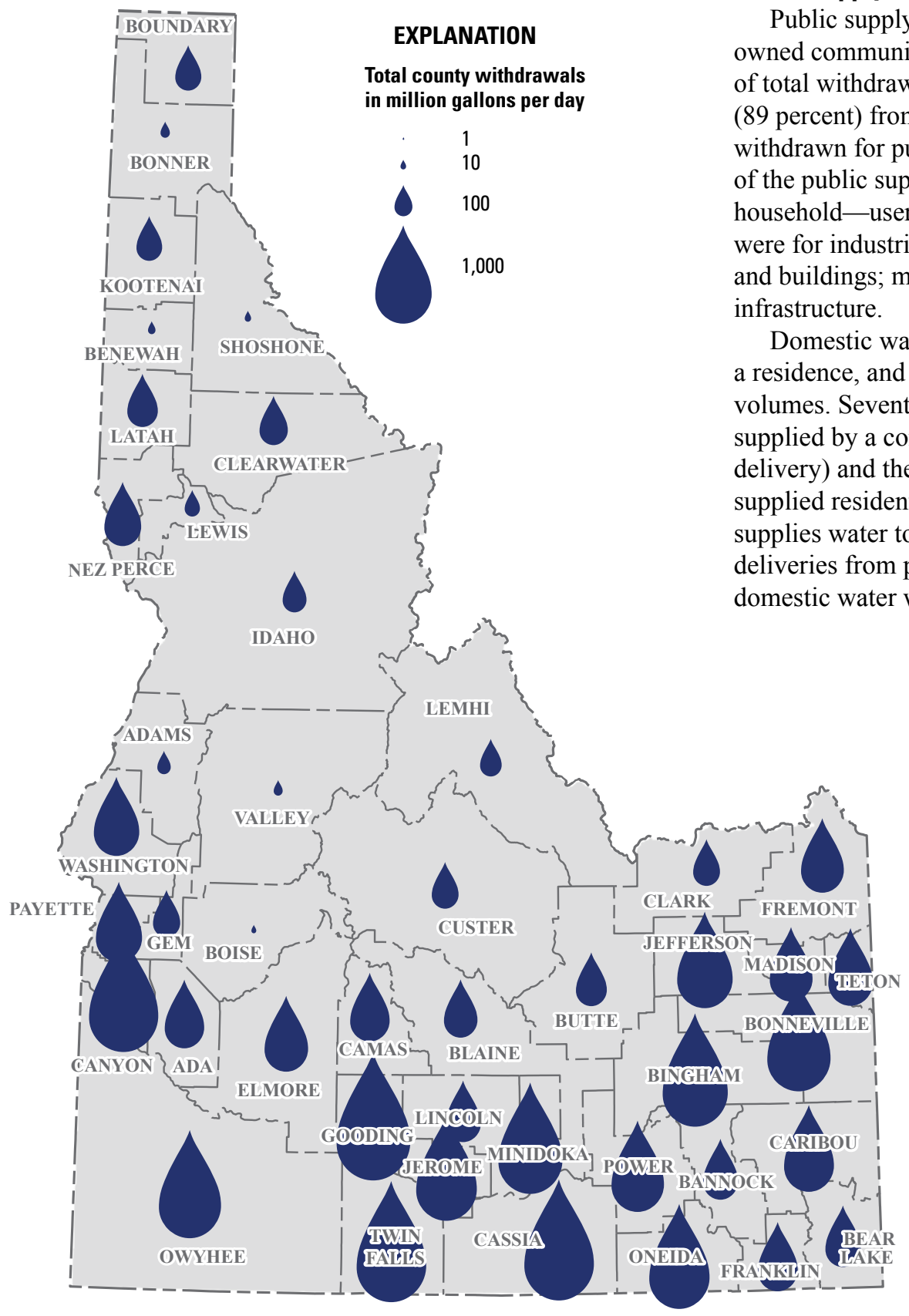

irrigation, and includes conveyance losses and consumptive use (evapotranspiration [ET] from crops and soil). Consumptive use by county is shown relative to the total irrigation withdrawal in figure 3 .

\section{Aquaculture-1,965 million gallons per day}

The second largest category of water use, aquaculture, was $1,965 \mathrm{Mgal} / \mathrm{d}$, accounting for 11 percent of total withdrawals in Idaho during 2015, 98 percent was from surface-water sources. Idaho has consistently ranked first in the Nation for aquaculture water use, as it was in 2015 (C.A. Dieter, U.S. Geological Survey, written commun., 2018) due to the use of flow-through raceways, the predominate type of facility used for aquaculture. Reported withdrawals represent the initial diversion to aquaculture operations, and these diverted flows return to the river after passing through the facility with relatively little water lost to evaporation.

Public Supply and Domestic Water-276 million gallons per day

Public supply includes all water withdrawn by a publicly owned community water system, and accounted for 1.6 percent of total withdrawals in Idaho during 2015, almost entirely (89 percent) from groundwater. In 2015, $276 \mathrm{Mgal} / \mathrm{d}$ were and buildings; maintenance of water systems; or lost by leaky frastructure.

Domestic water includes indoor and outdoor water used at a residence, and includes self-supplied and publicly supplied volumes. Seventy-six percent of Idaho residents have water supplied by a community water system (a public supply delivery) and the remaining 24 percent are self-supplied. Selfsupplied residents either own a well or connect to a well that supplies water to less than 20 residences. In 2015, domestic eliveries from public supply were $234 \mathrm{Mgal} / \mathrm{d}$ and self-supplied domestic water withdrawals were $70 \mathrm{Mgal} / \mathrm{d}$.

Figure 2. Withdrawals by county in Idaho, 2015. Water use is highest in southern Idaho counties where irrigated agriculture is prevalent. 
In 2015, Idaho households had the highest per capita domestic water use in the Nation. The 2015 statewide average was 184 gallons per person per day, and was 102 gallons per person per day higher than the National average (Dieter and Maupin, 2017). The high domestic per capita use in Idaho is common across the Western United States because the dry climate leads to more household water that is used for lawn and garden irrigation. In 2015, domestic per capita water use was at or below the National average of 82 gallons per person per day in only five counties in Idaho: Bear Lake, Bingham, Bonner,

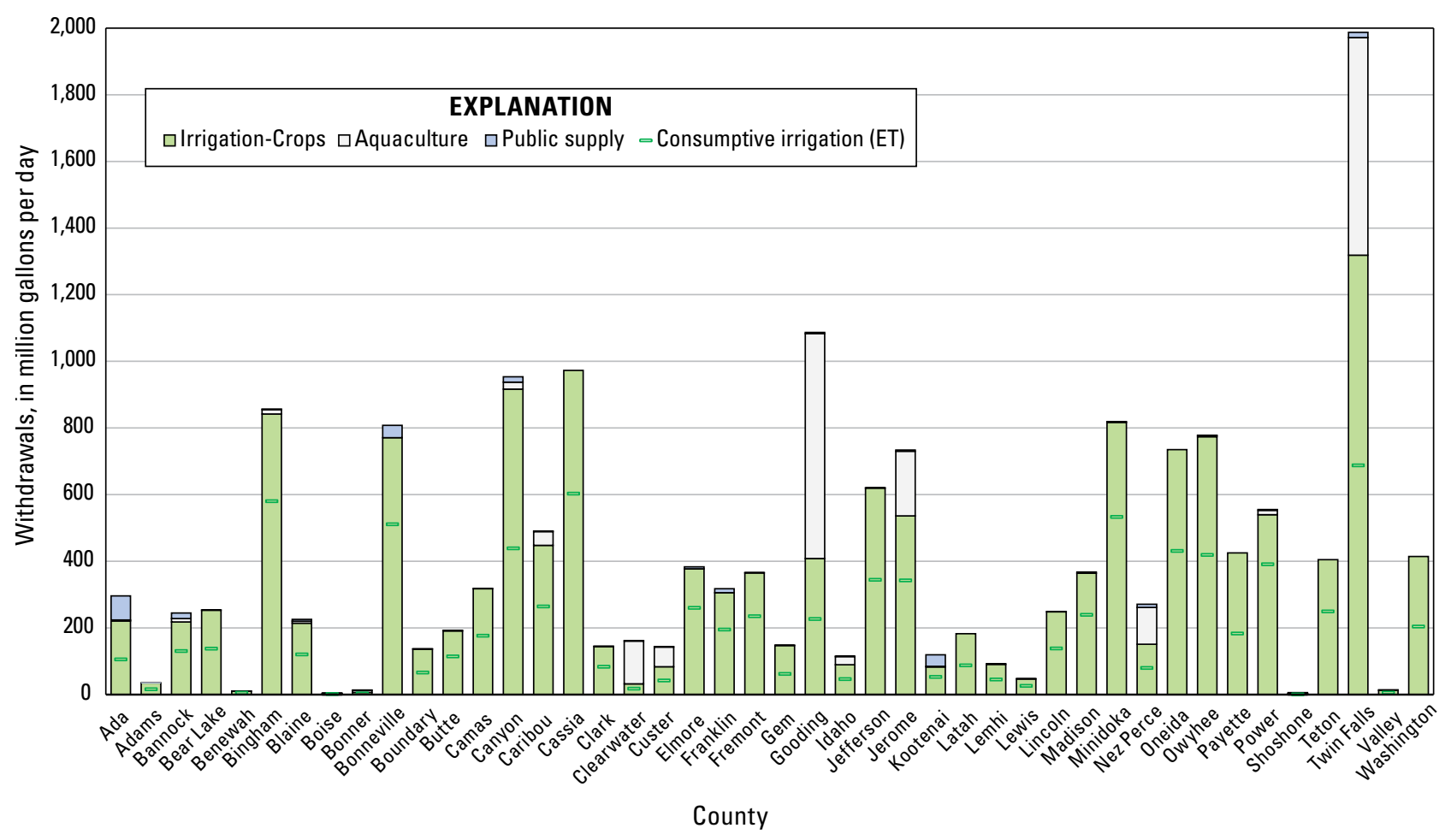

Figure 3. Withdrawals by major category within each county in Idaho.

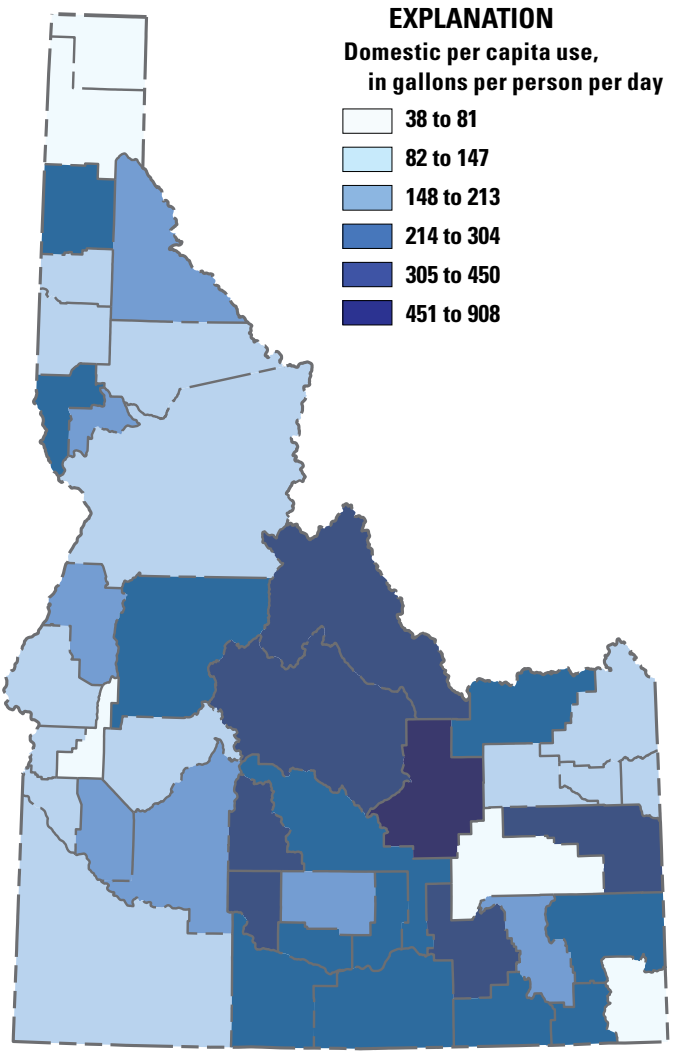

Figure 4.-Gross per capita domestic water use in Idaho, 2015.

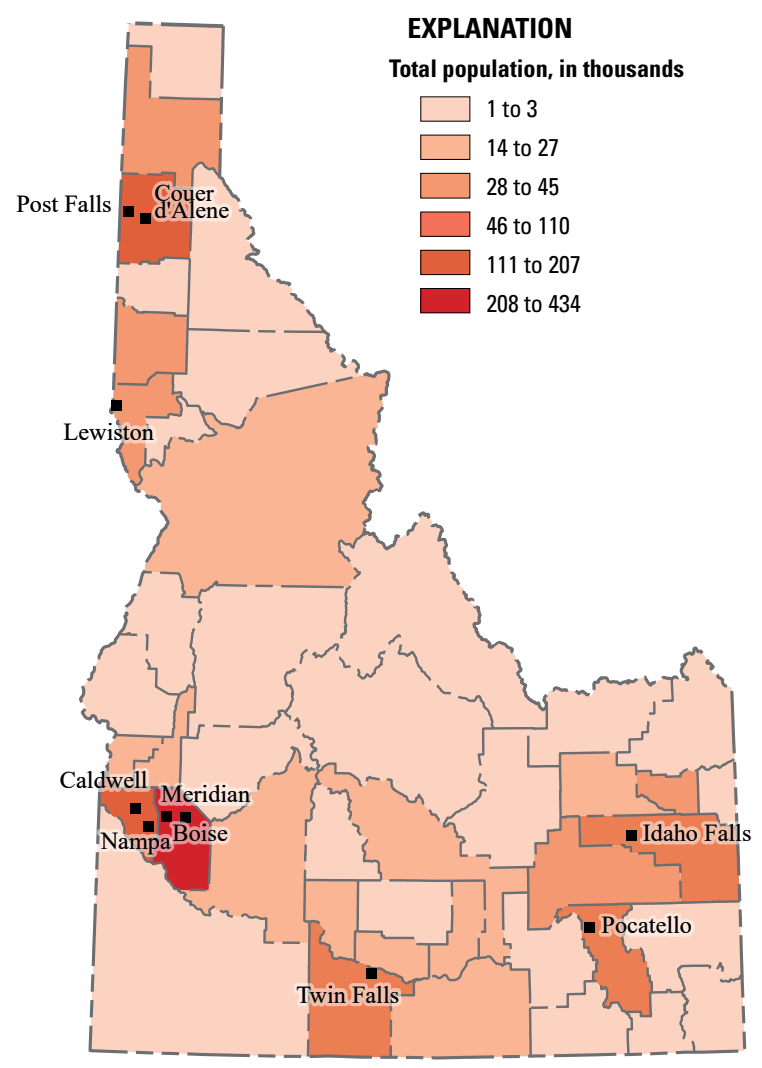

Figure 5. Total population of Idaho in 2015. 
Boundary, and Gem Counties (fig. 4). Idaho is largely a rural state, with an approximate population of 1.7 million in 2015 . Some counties have low populations with small total amounts of water withdrawals despite their high per capita domestic use (fig. 5).

\section{Trends, 1985-2015}

Idaho withdrew the third largest quantity of water in the Nation in 2015 (C.A. Dieter, written commun., 2018), and changes in withdrawals over time are important in discussions of water resources at a National level. Idaho has seen steady population growth since 1990 (fig. 6), but total water withdrawals have remained steady or have slightly decreased in that time. The public supply population (those supplied water by a community water system) increased from 2010 to 2015 , whereas the self-supplied population decreased. About 40 percent of this population growth occurred in Ada and Canyon Counties. Because irrigation dominates water withdrawals in Idaho, fluctuations in total withdrawals year-to-year largely depend on changes in irrigation withdrawals, and therefore will vary with weather patterns and irrigation practices.

\section{Future Needs}

A better understanding and quantification of the top three water uses - irrigation of crops, aquaculture, and public and (or) domestic supply - would provide improved estimates of water use at the State level. Because most withdrawals in Idaho are used to irrigate crops, it is especially crucial to understand water use in agricultural counties. Local climate conditions affect water demand during the growing season, and more research is needed to quantify these seasonal variations in water use for irrigation. Aquaculture accounts for the second largest amount of water withdrawals in Idaho. However, much of the water withdrawn for aquaculture is returned to the local source (river or stream). Quantifying the consumptive use of water withdrawn for aquaculture would help to understand its importance relative to the water that returns to the water cycle. As the population of Idaho continues to grow, water managers would benefit from more detailed water use information in rapidly growing urban centers. It may be important to understand why Idaho has the highest rate of domestic per capita use in the Nation and it may be of particular importance to investigate what amount of domestic withdrawals are being used to irrigate lawns and gardens. In Ada and Canyon Counties, which include a population center with high irrigation withdrawals, increased urban development may dramatically increase or decrease water use over time as land use changes.

Estimating water use more often than every 5 years, and at sub-county levels would provide a better spatial and temporal resolution of the human demand on water resources in Idaho. The diversity across the State in climate, population, and land use contributes to the varied water use by category in Idaho counties. Continued monitoring of the human effects on the hydrologic cycle will help ensure that demands can be balanced with water availability from a local to global scale.

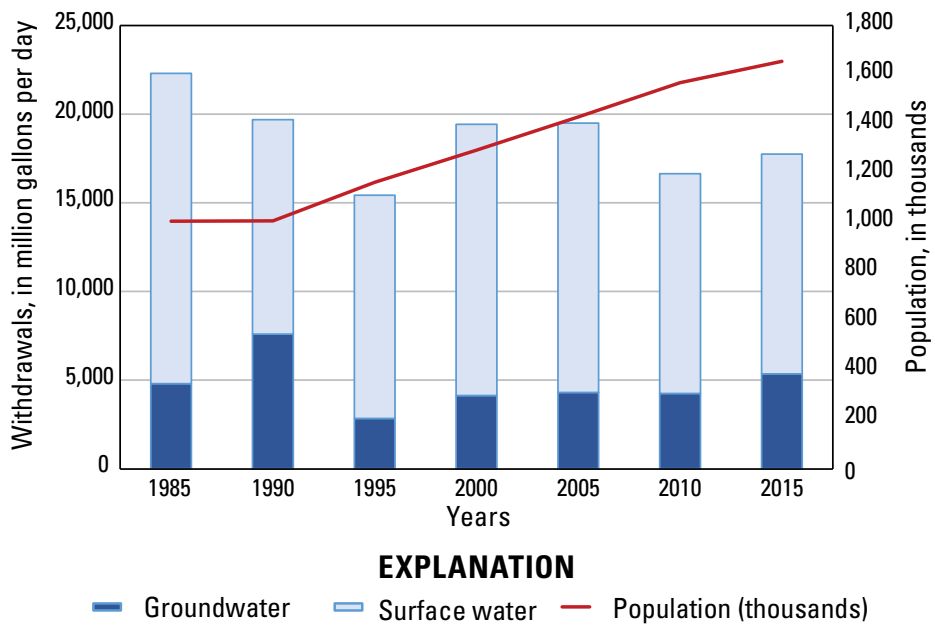

Figure 6. Withdrawals by source in Idaho, 1985-2015.

\section{Acknowledgments}

Valuable data and (or) support for this study were provided by the Idaho Department of Water Resources; Idaho Department of Environmental Quality; U.S. Department of Agriculture (NASS, NRCS, and Idaho extension offices); Idaho Golf Course Superintendents Association; Idaho Department of Fish and Game; U.S. Fish and Wildlife Service; Bureau of Reclamation; U.S. Census Bureau; Idaho Department of Commerce; University of Idaho; U.S. Energy Information Administration; U.S. Geological Survey Water-Use Availability and Use Science Program; and many city and county offices in Idaho.

\section{References Cited}

Dieter, C.A., and Maupin, M.A., 2017, Public supply and domestic water use in the United States, 2015: U.S. Geological Survey Open-File Report 2017-1131, 6 p., https:// doi.org/10.3133/ofr20171131.

Dieter, C.A., Maupin, M.A., Caldwell, R.R., Harris, M.A., Ivahnenko, T.I., Lovelace, J.K., Barber, N.L., and Linsey, K.S., 2018, Estimated use of water in the United States in 2015: U.S. Geological Survey Circular 1441, 65 p., https://doi.org/10.3133/cir1441. [Supersedes USGS Open-File Report 2017-1131.]

Murray, E.M., 2018, Water use by source and category in Idaho counties, 2015: U.S. Geological Survey data release, https://doi.org/10.5066/P92AXN0O.

\section{Author:}

Erin M. Murray

For more information:

U.S. Geological Survey, 230 Collins Road, Boise, Idaho 83702

https://www.usgs.gov/centers/id-water

Publishing support provided by the U.S. Geological Survey, Tacoma Publishing Service Center 